\title{
EFFECT OF INJECTION TIMING IN LHR DIESEL ENGINE USING SIMAROUBA BIODIESEL BLENDS AS FUEL
}

\author{
Anjaneya G ${ }^{1}$, Prabhakar Reddy $C^{2}$, Udaya Ravi $\mathbf{M}^{\mathbf{3}}$, Ravindranath $\mathrm{K}^{\mathbf{4}}$ \\ ${ }^{1,2,3} R \& D$ Centre, Department of Mechanical Engineering, Sri Venkateshwara College of Engineering, Vidyanagar, \\ Kempegowda International Air-port Road, Bengaluru-562 157 \\ ${ }^{4}$ Professor Emeritus, Sri Venkateswara College of Engineering \& Technology, Chittoor, AP \\ ${ }^{1}$ Ph. D Research Scholar, Tel:-+91-9886413616, E-mail:-anju.gorkal@gmail.com
}

\begin{abstract}
Experiments were conducted on a single cylinder air cooled Conventional Engine (CE) and Low Heat Rejection (LHR) diesel engine using Simarouba Biodiesel Blends (SBD10, SBD20 and SBD30) as substitute fuel. Piston crown is coated with 300 microns of Partially Stabilized Zirconia (PSZ) to operate as LHR engine. Conventional Engine was run with diesel andbiodiesel blends at 200 bar injection pressure and injection timing of $23^{\circ}$ before top dead centre (btdc) to get base line data at varying load conditions $\left(0,25 \%, 50 \% .75 \%\right.$ and $100 \%$ of full load). LHR engine was made to run with blends at three injection timings of $23^{\circ}$, $20^{\circ}$ (retarded) and $26^{\circ}$ (advanced) btdc respectively. The performance parameters such as Brake Thermal Efficiency (BTE), Brake Specific Fuel Consumption (BSFC), and Exhaust Gas Temperature (EGT) were considered, emissions $\left(\mathrm{CO}_{2}, \mathrm{HC}, \mathrm{NO}_{X}\right.$ and Filter Smoke Number-FSN) were recorded for both engines. The results showed that LHR engine with injection timing of $20^{\circ}$ btdc,significantly reduces emissions (in particular $N O_{X}$ ) for all blends compared to conventional diesel engine with slight loss in BTE.LHR engine with advanced injection timing showedenhanced BTE, reduced CO and HC emissions with NOxincreasing rapidly.
\end{abstract}

Keywords: LHR Diesel Engine, Biodiesel Blends, Partially Stabilized Zirconia, Injection Timing, Engine Performance and Emissions

\section{INTRODUCTION}

\subsection{Biodiesel}

Biodiesel is a mono-alkyl esters of long chain fatty acids obtained from vegetable oils or animal fats with or without using a catalyst. It is renewable, biodegradable, environmental friendly, non-toxic, handy, easily available fuel (Gaurav Dwivedi et al.2011). Biodiesel has low volatility because of higher molecular weight of the triglyceride molecule (Ashwani Kumar et. al) and have a slight range of viscosity changes with temperature. There are many ways to produce biodiesel fuel from vegetable oil such as Pyrolysis, dilution, micro emulsion and transesterification. The transesterification process is the most feasible and economical process (Shiv Kumar Lohan et al. 2013\&Hwai Chyuan Ong et al. 2014). Biodiesels from Soyabeen, Sunflower, Jatropha, Honge, Rubber seed and Simarouba are commonly considered as substitute for diesel fuel. Simarouba belongs to the family of Simaroubaceae Quasia, commonly known as paradise tree originated in North America. Simarouba is gaining economic importance in countries such as India, China, Myanmar and so on due to its properties comparable to diesel and other biodiesels (Abedin M.J et al. 2014\&C. Jena Prakash et al. 2010).

\subsection{Low Heat Rejection Engine}

The increased influence of global warming, inadequate efficiency of internal combustion engines, and stringent anti-pollution laws enforced researchers to explore more efficient engine with tolerable emission levels. The rapid exhaustion of fossil fuels and swift increase in fuel price also increased awareness of alternative fuels for IC engines. LHR is one of the many attempts to fathom and realize a less wasteful, eco-friendly yet competent IC engine.LHR engine insinuates those IC engine which reject less heat(Robert Vaben et al. 2010\&Abedin M.J et al. 2014) than normal IC engine by virtue of its thermal barrier coating on walls of combustion chamber (Hejwowski T et al. 2002, Ekrem Buyukkaya et al. 2008\&Robert Vaben et al. 2010).Key notion behind the concept of LHR is to reduce coolant heat loss and increase thermal efficiency (C. Jena Prakash et al. 2010). Based ondetailed literature survey, it is observed that the performance of LHR engine using Simarouba biodiesel with variable injection timing is not yet reported. Injection timing is one of the important variables and it influences efficiency and emission of the engine (Panneerselvam N et al. 2015 \& Ashrafur Rahman et al. 2014) is varied in the present study. The literature gapmotivated us to take up this project with Simarouba as biodiesel in LHRengine with variable injection timing. The foremost intent of the endeavor is to investigate the performance and emission of diesel and Simarouba biodiesel blendsin LHR engine.Biodiesel is prepared by transesterification process and its characterization is done. Piston crown is coated with PSZ(Cao X.Q et al. 2004\&Sivakumar G et al. 2014) by plasma spray technique after identifying suitable thickness through thermal analysis using ANSYSsoftware (Moridi A et al. 2014).The subsequent objective is to vary the injection timing (retarding and advancing) to reduce emission and simultaneously improve efficiency of LHRengine (Ekrem Buyukkaya et al. 2006) running with biodiesel blends. Fig. 1 shows piston crown before and after coating. 


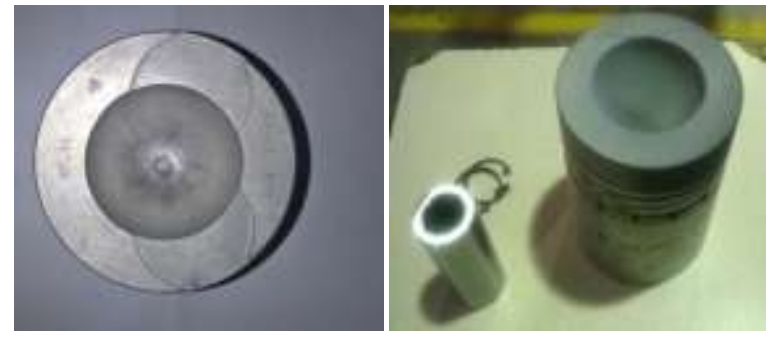

Fig. 1 Conventional and coated piston crown

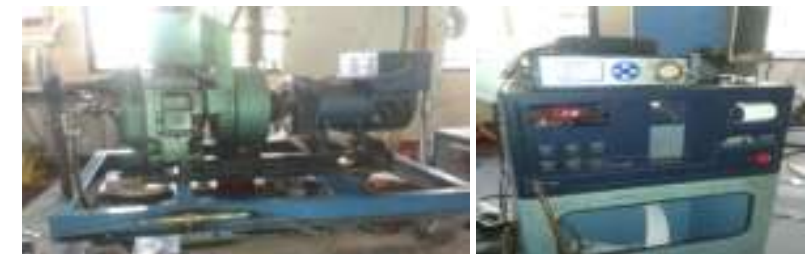

Fig.2 Diesel Engine Test Rig with AVL 444 DI gas analyzer and AVL 415 smoke meter

\section{EXPERIMENTAL STUDIES}

Experiments were conducted on a 4-stroke single cylinder air cooled diesel engine (Kirloskar TAF1) coupled with eddy current dynamometer. Air flow rate is determined using air box fitted with a sharp edge orifice. Fuel flow rate is computed by notingthe time for $20 \mathrm{cc}$ of fuel consumption bythe engine. Engine emissions such as $\mathrm{CO}_{2}, \mathrm{HC}$ and $\mathrm{NOx}$ were measured using AVL 444 DI gas analyzer. Smoke opacity i.e. FSNis measured using AVL 415 smoke meter. Fig. 2 shows test engine, gas analyser and smoke meter. Specifications of the test engine are presented in table 1. Table 2 shows properties of diesel and Simarouba biodiesel blends. The experiments were conducted with diesel and SBD10, 20 and 30with an injection timing of $23^{\circ}$ btdc using conventional engine. The conventional engine is converted into LHR engine by coating piston crown with 300 microns of PSZ. The experiments are repeated with diesel and Simarouba biodiesel blends in LHR engine with original timing $\left(23^{\circ} \mathrm{btdc}\right)$ and variable injection timings $\left(20^{\circ}\right.$ btdcand $26^{\circ}$ btdc). The results of performance and emissions obtained were analyzed and compared with diesel operation.

Table -1:Test Engine Specifications

\begin{tabular}{|l|l|}
\hline Description & Specification \\
\hline Make of the engine & Kirloskar TAF1 \\
\hline Number of cylinders & 1 \\
\hline Cycle & 4 stroke \\
\hline Injection & Direct injection \\
\hline Cooling & Air cooled \\
\hline Type of combustion chamber & hemispherical open type \\
\hline Bore & $87.5 \mathrm{~mm}$ \\
\hline Stroke & $110 \mathrm{~mm}$ \\
\hline Compression ratio & $17.5: 1$ \\
\hline Rated output & $4.4 \mathrm{KW}$ \\
\hline Speed & $1500 \mathrm{rpm}$ \\
\hline Injection pressure & $200 \mathrm{bar}$ \\
\hline Injection timing & 23 deg. before TDC \\
\hline Injector nozzle & 3 hole nozzle \\
\hline
\end{tabular}

Table -2: Diesel and Simarouba biodiesel blends' properties

\begin{tabular}{|c|c|c|c|c|c|}
\hline Properties & Diesel & SBD & $\begin{array}{c}\text { SBD } \\
10\end{array}$ & $\begin{array}{c}\text { SBD } \\
20\end{array}$ & $\begin{array}{c}\text { SBD } \\
\text { 30 }\end{array}$ \\
\hline $\begin{array}{l}\text { Flash point } \\
\left({ }^{0} \mathrm{C}\right)\end{array}$ & 54 & 160 & 60 & 67 & 72 \\
\hline $\begin{array}{l}\text { Fire point } \\
\left({ }^{0} \mathrm{C}\right)\end{array}$ & 64 & 178 & 67 & 74 & 85 \\
\hline $\begin{array}{l}\text { Density } \\
\left(\mathbf{k g} / \mathbf{m}^{3}\right)\end{array}$ & 840 & 903.9 & 827 & 831 & 835 \\
\hline $\begin{array}{l}\text { Kinematic } \\
\text { viscosity } \\
@ 4{ }^{0} \mathrm{C} \\
\text { (Cst) }\end{array}$ & 2.54 & 4.9 & 2.68 & 2.83 & 2.91 \\
\hline $\begin{array}{l}\text { Calorific } \\
\text { value } \\
(\mathrm{MJ} / \mathrm{kg})\end{array}$ & 42.5 & 38.42 & 42.4 & 41.4 & 40.2 \\
\hline
\end{tabular}

\section{RESULTS AND DISCUSSIONS}

\subsection{Brake Thermal Efficiency (BTE)}

Figs. 3, $4 \& 5$ show the variation of BTE with $\%$ of full load for diesel and Simarouba biodiesel blends for conventional and LHR engines. BTE increases with load in both engines up to $75 \%$ of full load for all blends and then drops.BTE of all three blends is lower than diesel in conventional engine. This is due to their lower calorific value and higher viscosity compared to diesel. BTE is the function of combustion temperature and viscosity of the fuel. It is observed that higher combustion chamber temperature in LHR engine resulted in improved BTE with all three blends in spite of their higher viscosity. The effect of retarded timing $\left(20^{\circ}\right.$ btdc) in LHR engine resulted in slightly decreased BTE with all the blends due to reduced combustion duration.This results in incomplete combustion and late heat release and pressure raise. Whereas advanced injection timing $\left(26^{0} \mathrm{btdc}\right)$ resulted in increased BTE with all three blends. The longer combustion duration along with higher temperature in combustion chamber due to coating resulted in better oxidation reactions. Percentage increase inBTE is highest with SBD20 and was $9.9 \%$ compared to diesel at $75 \%$ full load.

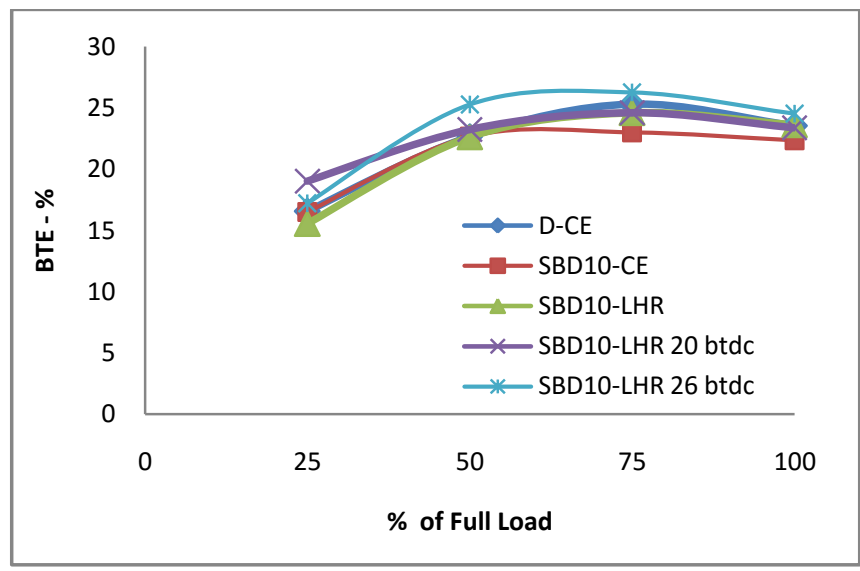

Fig.3 Variation of BTE with \% of Full load 


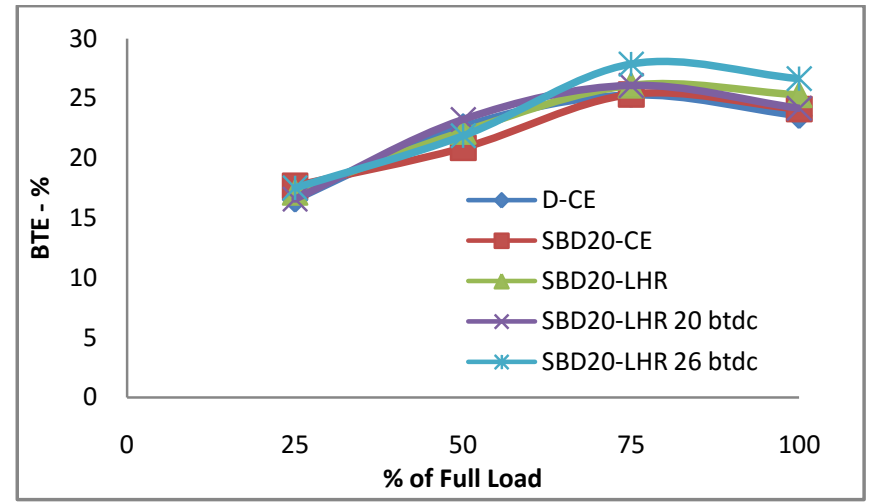

Fig.4 Variation of BTE with \% of Full load

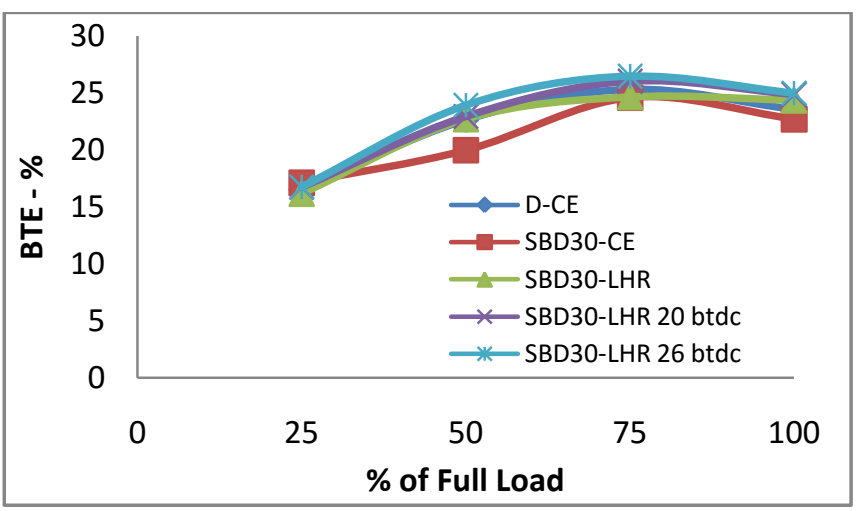

Fig.5 Variation of BTE with \% of Full load

\subsection{Brake Specific Fuel Consumption (BSFC)}

Figs. $6,7 \& 8$ show variation of BSFC with $\%$ of full load for diesel and Simarouba biodiesel blends in conventional and LHR engines. BSFC is higher at lower loads and is least at $75 \%$ of full load for all blends tested. BSFC is more forSimarouba biodiesel blends in a conventional engine as compared to diesel due to lower heating value and higher viscosity of the blends. In LHR engine BSFC is slightly decreased with blends compared to diesel due to better combustion. This may be due to higher combustion chamber temperatures. The retardationin LHR did not show any improvement in BSFC due to late and partial combustion. The advanced timing in LHRhelped greater improvement in BSFC with biodiesel blendsresultinginlonger combustion duration with more residence time for combustion.

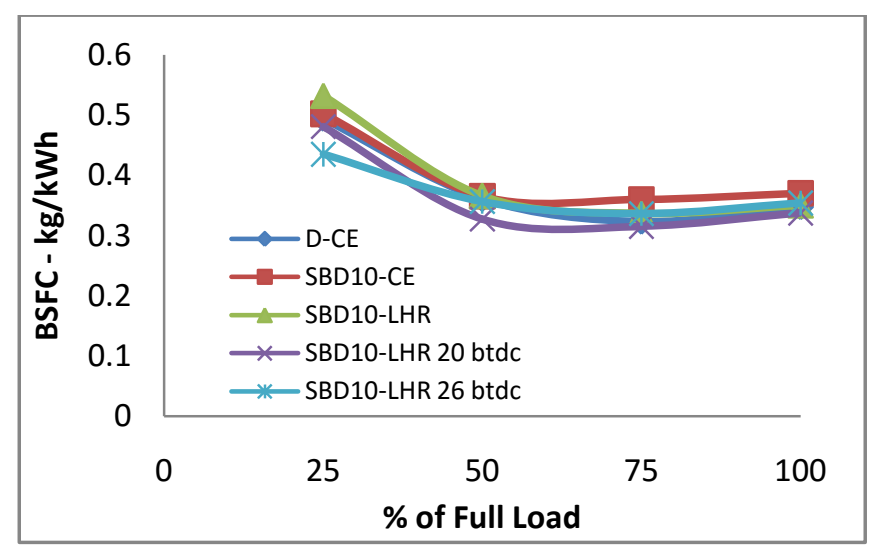

Fig. 6 Variation of BSFC with \% of Full load

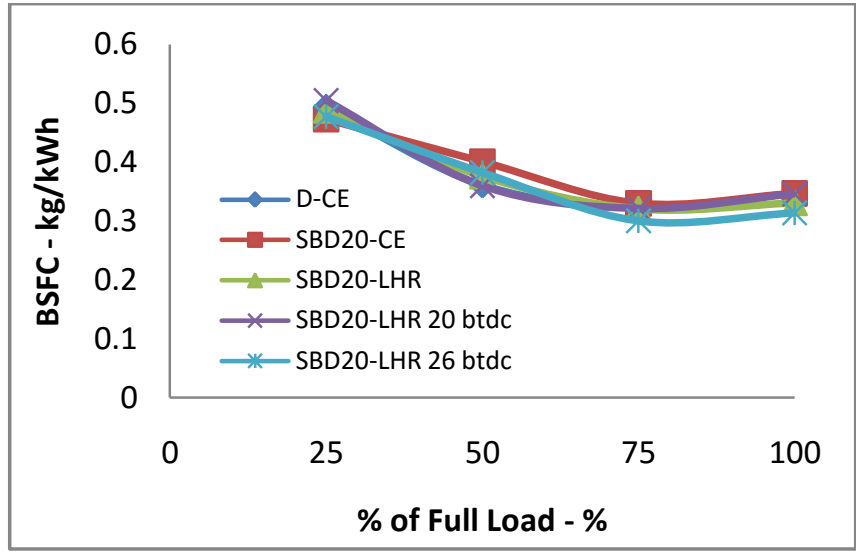

Fig. 7 Variation of BSFC with \% of Full load

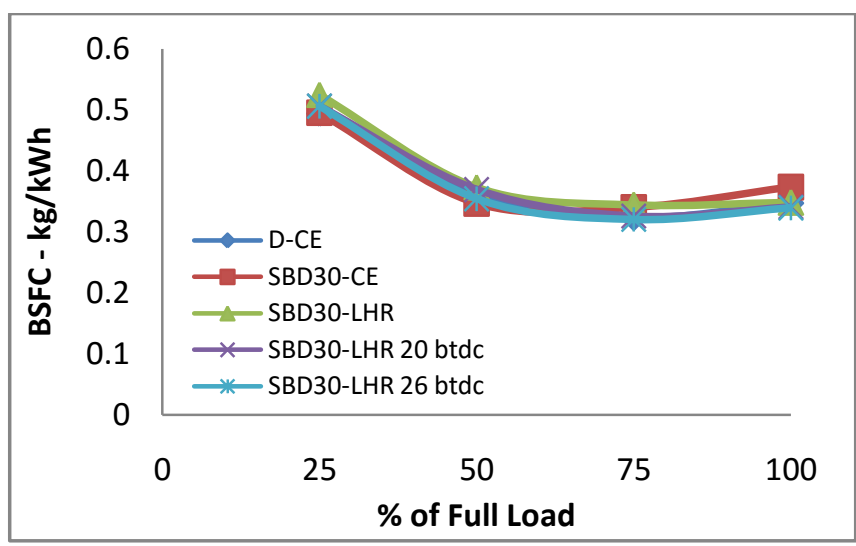

Fig. 8 Variation of BSFC with \% of Full load

\subsection{Exhaust Gas Temperature (EGT)}

Figs. 9, $10 \& 11$ show variation of EGT with \% of full load for diesel and simarouba biodiesel blends in conventional and LHR engines. EGT increases with load in both engines. LHR engine showed higher temperatures at all loads compared to diesel as a result of reduced heat losses to piston andcylinder walls due to PSZ coating on piston crown. EGT in case of biodiesel blends is less in conventional engine as compared to LHR engine. Advanced injection timing resulted in higher temperatures due to more residence time in LHR engine with all blends and is helpful in better combustion of blends.

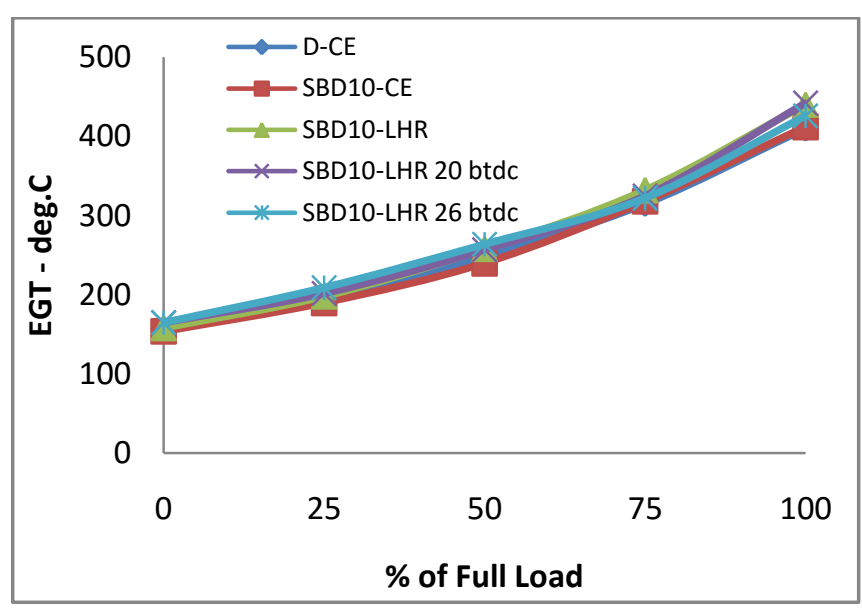

Fig. 9 Variation of EGT with \% of Full load 


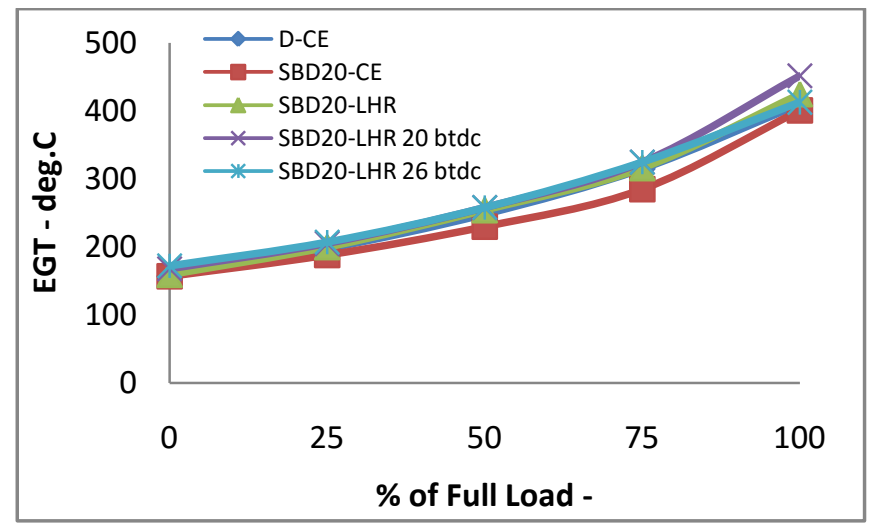

Fig. 10Variation of EGT with \% of Full load

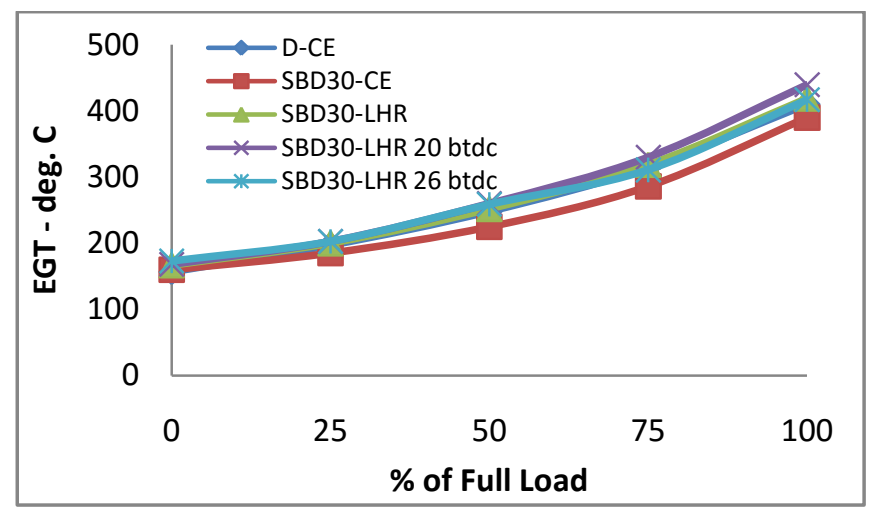

Fig. 11Variation of EGT with \% of Full load

\subsection{HC Emission}

Figs. 12, $13 \& 14$ show the variation of Hydrocarbon (HC) emissions with $\%$ of full load for conventional and LHR engines. As the Load increases, HC emission increases. HC emission decreased in conventional and LHR engines for all biodiesel blends compared to diesel. Since biodiesel is an oxygenated fuel this may enhance the combustion reactions and reduce $\mathrm{HC}$ emissions. $\mathrm{HC}$ emission is further decreased in LHR engine for all blends by advancing the injection timing. This is because of improved combustion using blends due to higher combustion temperatures followed with longer residence time.For LHR engine with all three injection timings, $\mathrm{HC}$ was decreased with blends at all loads compared to diesel. This may be due to combined effect of higher combustion temperature due to coating, presence of oxygen in biodiesel resulting in bettercombustion.

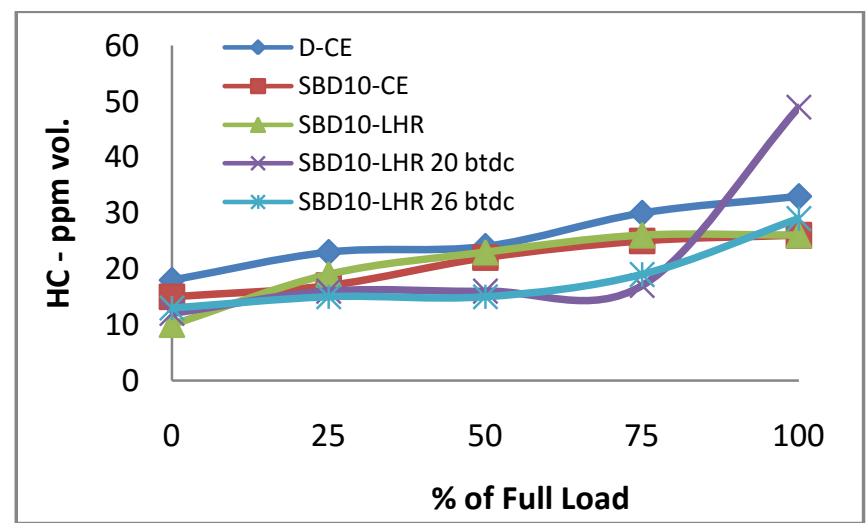

Fig.12Variation of HC emission with \% of Full load

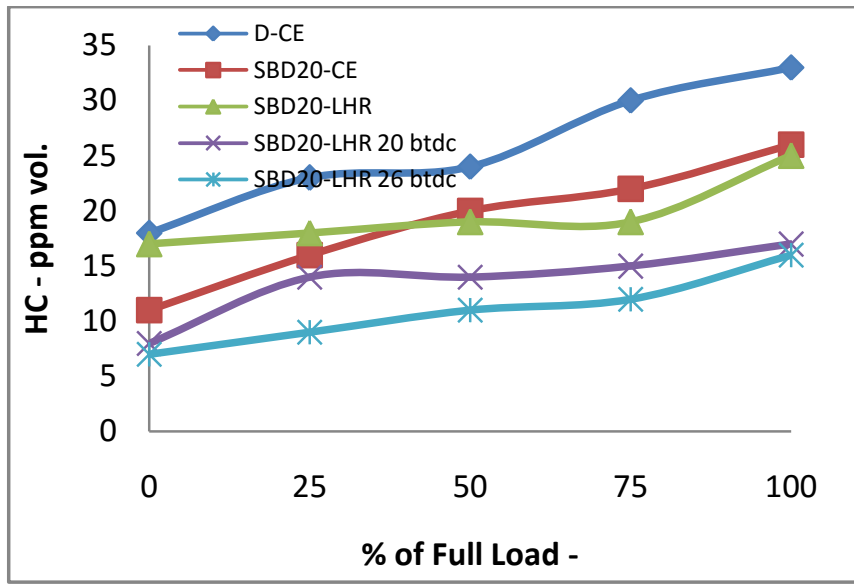

Fig.13Variation of HC emission with \% of Full load

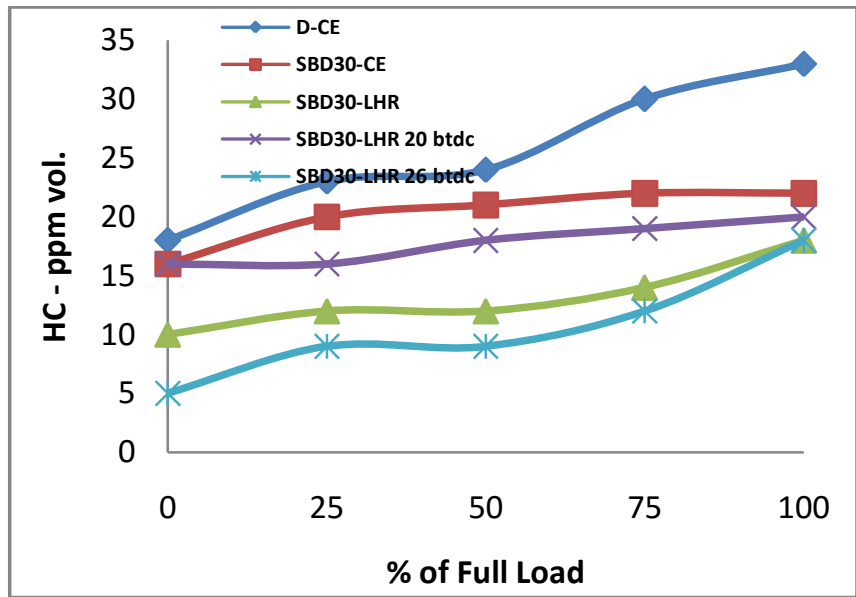

Fig. 14 variation of HC emission with \% of Full load

\section{5 $\mathrm{CO}_{2}$ Emission}

Figs.15, $16 \& 17$ show the variation of $\mathrm{CO}_{2}$ emission with load for conventional and LHR engines. $\mathrm{CO}_{2}$ emission increases with load. $\mathrm{CO}_{2}$ emission is more in diesel engine compared with biodiesel in conventional as well as LHR engines. This is mainly because of lower carbon percentage present in biodiesel. $\mathrm{CO}_{2}$ emission with biodiesel blends is higher at all loads in LHR engine compared to conventional engine indicating proper combustion. LHR engine with advanced timing showed slight higher $\mathrm{CO}_{2}$ emission with biodiesel blends due to better combustion.

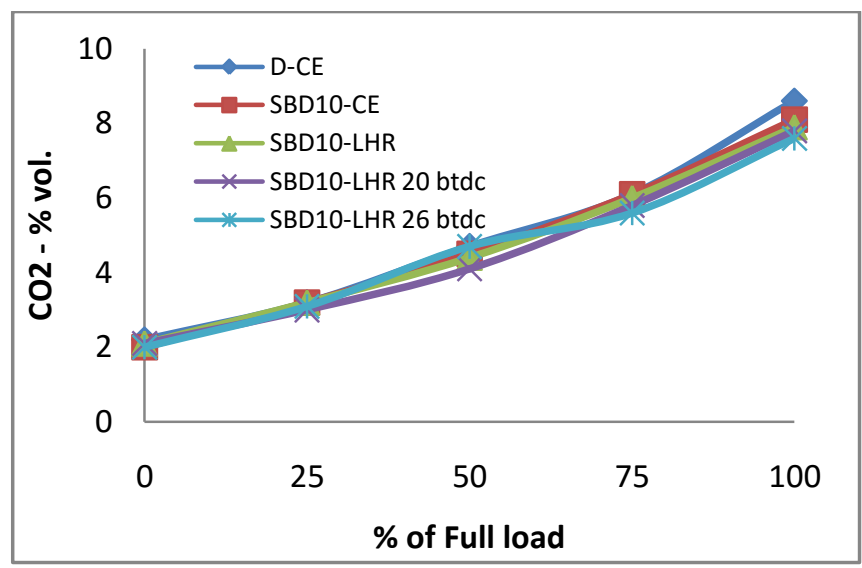

Fig. 15 Variation of $\mathrm{CO}_{2}$ emission with $\%$ of Full load 


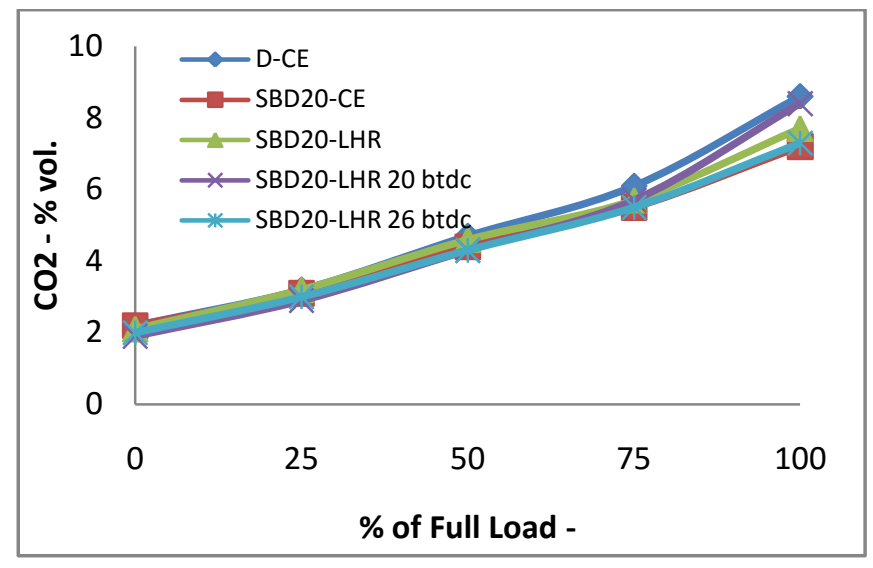

Fig. 16Variation of $\mathrm{CO}_{2}$ emission with $\%$ of Full load

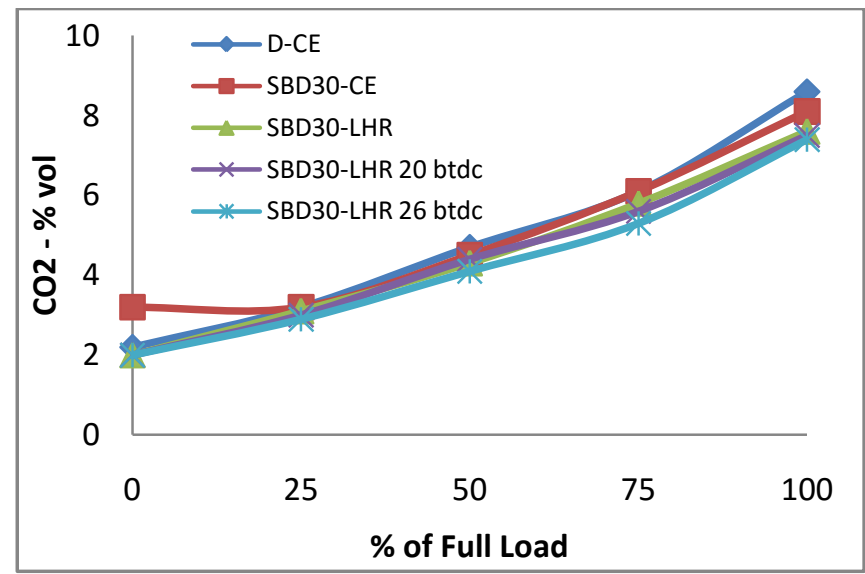

Fig. 17 variation of $\mathrm{CO}_{2}$ emission with \% of Full load

\subsection{Filter Smoke Number (FSN)}

Figs. 18, $19 \& 20$ show the variation of FSN with \% of full load for conventional and LHR engines. FSN is an indication of smoke opacity. Higher the number indicates higher smoke opacity. FSN increased with increase in load. FSN is less in LHR engine with biodiesel blends compared to diesel. LHR with retardation resulted in higher FSN with blends due to incomplete combustion. This may be due to shorter delay as well as shorter combustion time. LHR with advanced timing resulted lesser FSN with all blends due to better combustion because of longer delay and combustion time.

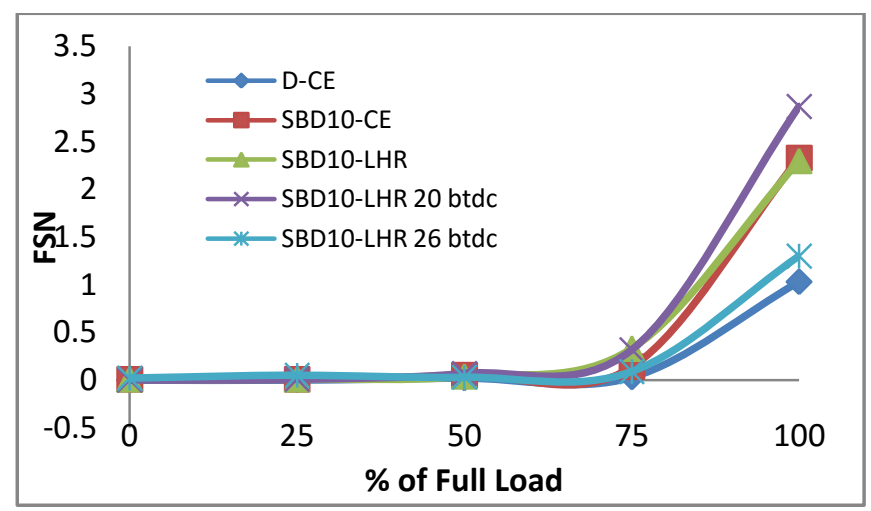

Fig. 18 Variation of FSN with \% of Full load

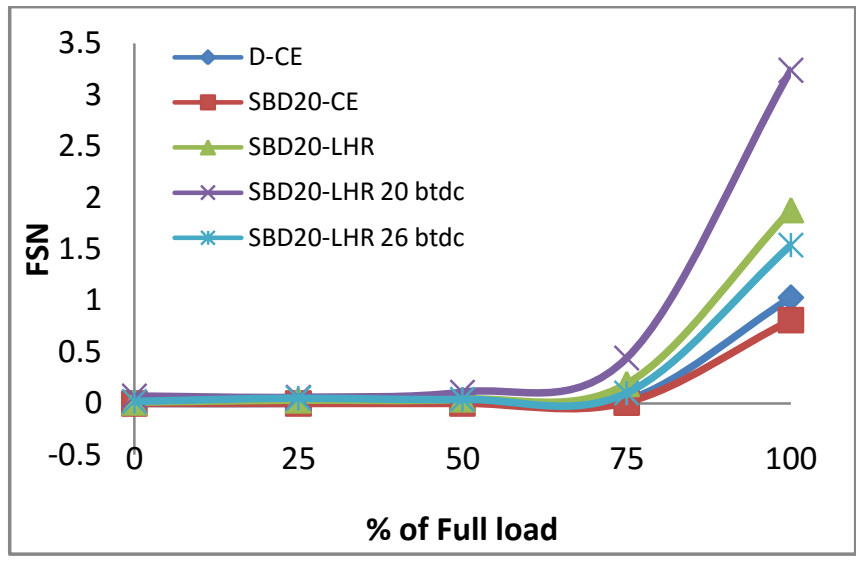

Fig. 19 Variation of FSN with \% of Full load

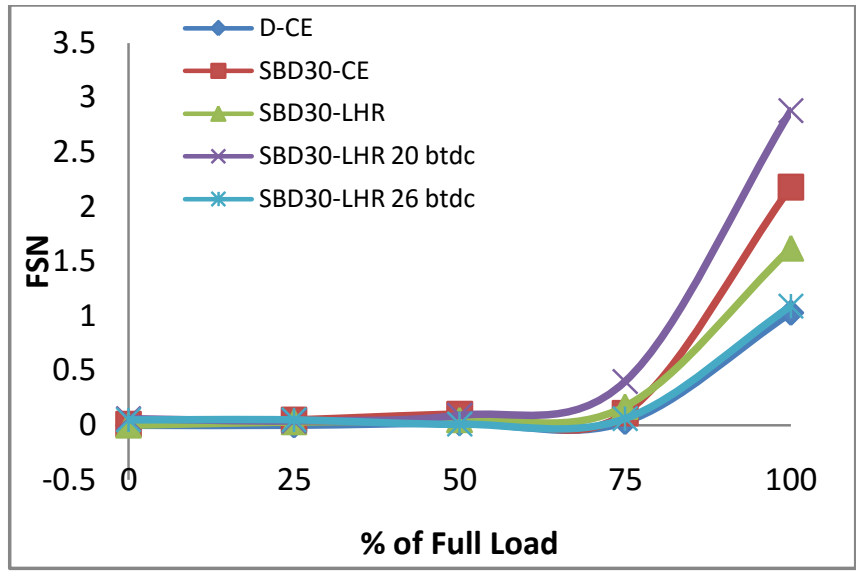

Fig. 20Variation of FSN with \% of Full load

\subsection{NO ${ }_{x}$ Emission}

Figs. 21, $22 \& 23$ show the variation of $\mathrm{NO}_{\mathrm{X}}$ with\% of full load for conventional and LHR engines. $\mathrm{NO}_{\mathrm{X}}$ increased with advancement in injection timing in LHR engine as a result of longer combustion duration. The reason is more air and fuel mixture is burnt in premixed combustion stage due to longer dealy. By retardation, combustion duration gets decreased and residence time reduced and overall combustion becomes partial and hence $\mathrm{NO}_{\mathrm{x}}$ decreased.

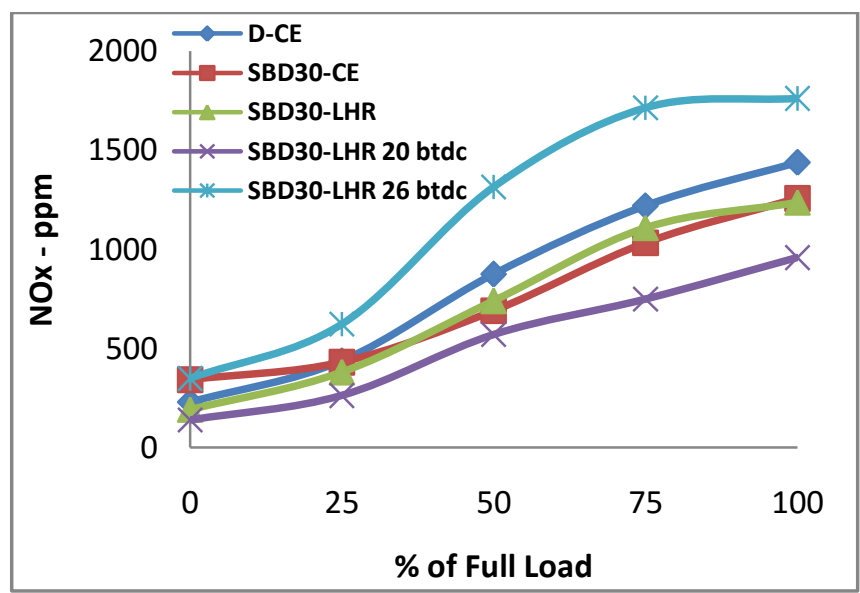

Fig. 21 Variation of $\mathrm{NO}_{\mathrm{x}}$ emission with \% of Full load 


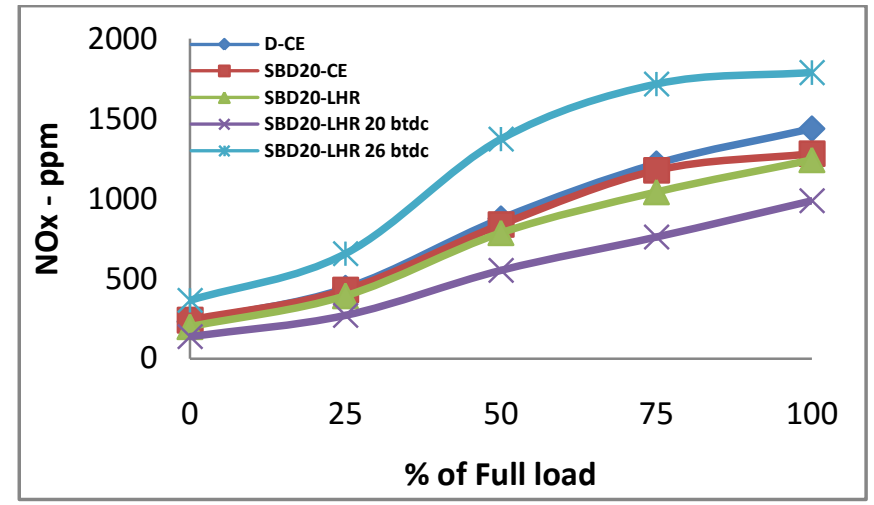

Fig. 22Variation of $\mathrm{NO}_{\mathrm{x}}$ emission with \% of Full load

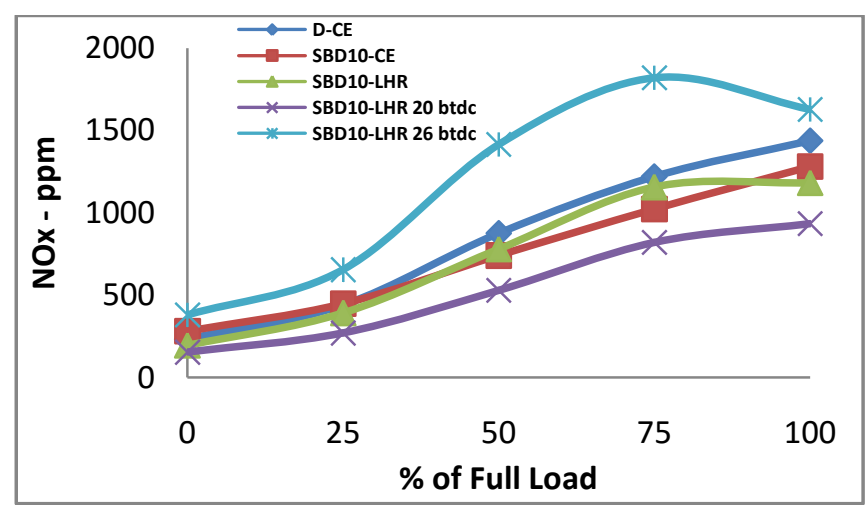

Fig. 23Variation of $\mathrm{NO}_{\mathrm{x}}$ emission with $\%$ of Full load

\section{CONCLUSIONS}

Experiments are conducted on single cylinder air cooled diesel engine using Simarouba Biodiesel blends as substitute fuel by varying injection timings and the following conclusions are drawn.

1. Amongst three blends tested in LHR engine with advanced injection timing $\left(26^{0} \mathrm{btdc}\right)$ SBD20 has shown higher BTE, lower BSFC and lower HC and FSN emission compared to diesel and other two blends.

2. For SBD20 by advancing injection timing, the percentage increase in BTE is $9.9 \%$ and percentage decrease in BSFC is $2.32 \%$ at $75 \%$ of full load compared to diesel.

3. In LHR engine $\mathrm{HC}$ and FSN are reduced by advancing the injection timing with biodiesel blends

4. $\mathrm{NO}_{\mathrm{x}}$ wassignificantly reduced for allblends in LHR engine by retarding injection timing at all load conditions compared to conventional diesel. Whereas with advanced injection timing $\mathrm{NOx}$, is increased rapidly at all load conditions.

5. The percentage decrease in $\mathrm{NO}_{\mathrm{x}}$ with $\mathrm{SBD} 20$ is $24.82 \%$ at $75 \%$ of full load compared to diesel by retarding injection timing.

6. LHR engine with retardation is suitable for biodiesel blends as it decreases harmful $\mathrm{NO}_{\mathrm{x}}$ emission compared to diesel.

7. LHR with advanced injection timing is preferred for biodiesel blends to increase BTE provided $\mathrm{NO}_{\mathrm{x}}$ is controlled by adopting catalytic converters in the exhaust pipe.
8. Simarouba biodiesel blends can be used as a potential oil as a substitute to diesel.

\section{REFERENCES}

[1] Gaurav Dwivedi, Siddharth Jain, Sharma M.P. "Impact analysis of biodiesel on engine performance-A review", Renewable and Sustainable Energy Reviews, vol.15, 2011, pp.4633-4641.

[2] Ashwani Kumar, Satyawati Sharma "Potential nonedible oil resources as biodiesel feedstock: An Indian perspective", Renewable and Sustainable Energy Reviews, vol.15, 2011, pp.1791-1800.

[3] Shiv Kumar Lohan, Ram T., Mukesh S., Ali M., Arya S. "Sustainability of biodiesel production as vehicular fuel in Indian perspective", Renewable and Sustainable Energy Reviews, vol.25, 2013, pp.251-259

[4] Hwai Chyuan Ong, Masjuki H.H., Mahlia T.M.I. , Silitonga A.M., Chong W.T., Leong K.Y. "Optimization of biodiesel production and engine performance from high free fatty acid Calophyllum inophyllum oil in CI diesel engine", Energy Conversion and Management, vol.81, 2014, pp.30-40.

[5] Abedin M.J., Masjuki H.H., Kalam M.A., Sanjid A., Ashraful A.M. "Combustion, performance, and emission characteristics of low heat rejection engine operating on various biodiesels and vegetable oils", Energy Conversion and Management, vol.85, 2014, pp. 173-189

[6] C. Jena Prakash, Hifjur Raheman, Prasanna Kumar G.V., Rajendra Machavaram "Biodiesel production from mixture of mahua and simarouba oils with high free fatty acids", Biomass and Bio energy, vol.34, 2010, pp.1108-1116. Hejwowski T., Weronski A. "The effect of thermal barrier coatings on diesel engine performance", Vacuum, vol. 65, 2002, pp.427-432.

[7] Robert Vaben, Maria Ophelia Jarligo, Tanja Steinke, Daniel Emil Mack, Detlev Stover "Overview on advanced thermal barrier coatings", Surface \& Coatings Technology, vol.205, 2010, pp.938-942

[8] Ekrem Buyukkaya, Muhammet Cerit "Experimental study of NOx emissions and injection timing of a low heat rejection diesel engine", International Journal of Thermal Sciences, vol. 47, 2008, pp.1096-1106.

[9] Panneerselvam N., Murugesan A., Vijayakumar C., KumaravelA., Subramaniam D., Avinash A. "Effects of injection Timingon biodiesel fuelled engine characteristics-An overview", Renewable and Sustainable Energy Reviews, vol.50, 2015, pp.17-31.

[10] Ashrafur Rahman S.M. , Masjuki H.H., Kalam M.A., Sanjid A., Abedin M.J. "Assessment of emission and performance of compression ignition engine with varying injectiontiming", Renewable and Sustainable Energy Reviews, vol.35, 2014, pp.221-230.

[11] Cao X.Q., Vassen R., Stoever D. "Ceramic materials for thermal barrier coatings", Journal of the EuropeanCeramic Society, vol.24, 2004, pp.1-10.

[12] Moridi A., Azadi M., Farrahi G.H. "Thermomechanical stress analysis of thermal barrier coating system considering thickness and roughness effects", 
Surface \& CoatingsTechnology, vol.243, 2014, pp. 9199.

[13]Ekrem Buyukkaya, Tahsin Engin, Muhammet Cerit "Effects of thermal barrier coating on gas emissions and performance of a LHR engine with different injection timings and valveadjustments", Energy Conversion and Management, vol.47, 2006, pp.1298-1310.

[14] Sivakumar G., Senthil Kumar S. "Investigation on effect of Yttria Stabilized Zirconia coated piston crown on performance and emission characteristics of a diesel engine",Alexandria Engineering Journal, vol.53, 2014, pp.787-794 